\title{
Mobile Learning as a Solution for Restricted Learning during the COVID-19 Pandemic
}

\author{
Donnalyn Blacer Bacolod ${ }^{1 *}$ (D)
}

${ }^{1}$ Palawan State University, Puerto Princesa City, PHILIPPINES

*Corresponding Author: dbacolod@psu.palawan.edu.ph

Citation: Bacolod, D. B. (2022). Mobile Learning as a Solution for Restricted Learning during the COVID-19 Pandemic. Journal of Digital Educational Technology, 2(1), ep2203. https://doi.org/10.21601/jdet/11584

\section{ARTICLE INFO}

Received: 21 Nov. 2021

Accepted: 16 Jan. 2022

\begin{abstract}
The proliferation of smartphones and web technology 2.0 raises the possibilities for supporting mobile learning during the COVID-19 outbreak. This quantitative research attempted to justify the use of mobile learning as a potential tool to fill the gap of restricted learning in higher education during this COVID-19 crisis. Respondents were chosen through multi-stage random sampling. A total of 116 teachers and 291 students from a state university in the Philippines answered the online survey. As results indicated, mobile internet access through smartphones was the primary educational gadget used by the students nowadays. They were familiar with mobile learning however they had little experience in the utilization of it before the pandemic crisis. Most of the teachers and students viewed mobile learning as an indispensable learning tool and agreed about its significance during this time of restricted learning despite some difficulties in implementation. However, some teachers and the majority of the students resisted using m-learning after the crisis. Such reasons must be addressed by the institution to ensure the effective implementation of m-learning for learning continuity nowadays and for the possible transition into $\mathrm{m}$-learning in the future. It is also crucial to consider the qualitative part of this study to shed more light on the perception of the respondents and the veracity of the results.
\end{abstract}

Keywords: restricted learning, technology, education, online learning, pandemic

\section{INTRODUCTION}

The 2019 coronavirus (COVID-19) which came from extreme acute coronavirus syndrome 2 (SARS-CoV-2) was declared a pandemic on the 12th March 2020 by the World Health Organization (WHO). Many institutions around the globe have been taken by surprise with the unprecedented occurrence of the COVID-19 pandemic. Undeniably, education is one of the affected sectors (UNESCO, 2020). Governments around the world struggle to contain the virus through the implementation of different measures such as social distancing, face-to-face restrictions, sudden school closure, and travel bans, among others. While these nonpharmaceutical strategies are adopted, the continuation of schooling at all levels is impacted. UNESCO (2020) reported that as of April 4, 2020, over 1.5 billion learners worldwide were unable to enter school or university due to the pandemic.

Several problems are now surfacing as the opening of classes is fast approaching. One major dilemma faced by higher education is the continuity of learning in an inhibited direct interaction and face-to-face contact between students and teachers. This brought chaos to many schools that are bounded by traditional instructions. Online and distance education are not new in developed countries, but for many developing countries like the Philippines, such a paradigm shift has not fully taken place. As such, a sudden collapse of education from primary to tertiary education became inevitable with the outbreak of the pandemic in the country. Educators and policymakers had little opportunity to address the sudden shifts surrounding their jurisdictions.

Transforming their face-to-face lessons into flexible learning was a big question mark. Indeed, COVID-19 pandemic has significantly altered the higher education framework of many countries. These experiences reveal important lessons to ponder upon by educators and policymakers. It is necessary to make education less reliant on place and time and increase learning versatility (Lakhal et al., 2017). Its drastic effects on education are now being addressed to ensure the continuity of learning. With issues of alienation between teacher and students, and the need to continue learning despite some restrictions, a pedagogical design that is not vulnerable to certain disruptions like natural disasters and pandemic arises as one possible solution. Adoption of mobile learning is a prevalent yet innovative solution for restricted learning given all these sudden changes.

The state university being surveyed in this study is a government-funded university established in the province of 
Palawan, the Philippines, in 1965. It has 8 colleges in the main campus such as College of Arts and Humanities (CAH), College of Sciences (CS), College of Nursing and Health Sciences (CNHS), College of Teacher Education (CTE), College of Business Accountancy (CBA), College of Hospitality Management and Tourism (CHMT), College of Criminal Justice Education (CCJE), and College of Engineering and Architecture Technology (CEAT); and accommodates more than 8,000 students not only in the province but across the country and the world. Like other schools in the country, the university has not been exempted from the unprecedented impact of the COVID-19 pandemic in the education sector primarily because its practices are embedded in the traditional face-to-face setup. The sudden outbreak of the pandemic last March 2020 resulted in school closure until June 2020. To continue the disrupted learning during those months, the university adopted the emergency remote teaching. The survey results of the university's Committee on the Development and Implementation of Flexible Learning Options (CODIFLO) last March 2020 revealed that most students own smartphones which can be primarily used for course-related activities and requirements and their primary access to the internet was through a wireless mobile device. Teachers resorted to using social media, google classroom, zoom, and other educational tools and practiced innovative pedagogies to keep the learning continuity possible during the early months of home quarantines and lockdowns. The adoption of currently available technologies such as videos, podcasts, and simple computer simulations are used to support educators and facilitate students' learning. While media platforms like Facebook, websites, and blogs can also provide opportunities for demonstrating essential skills (Dong \& Goh, 2015). All of which are accessible through smartphones and internet connectivity. The use of technology promotes adaptive learning that encourages all students to navigate a variety of learning opportunities and educate educators about how their interactions encourage students to learn (Goh \& Sandars, 2020). Mobile video tools and apps can also remotely coach students while staying at home.

The same media help reinforce the modular learning approach this new school year in the university. Apart from those, teachers considered the use of mobile networks and applications in their current teaching that encompasses mobile learning. Hence, the purpose of this paper is to offer a glimpse of the enabling capability of mobile learning in the education field during the COVID-19 pandemic. Also, this study explored the students' and teachers' prior exposure to mobile learning, as well as their perceptions and willingness to use mobile learning after the pandemic.

\section{Relevance of Mobile Learning}

Mobile learning or m-learning is an emerging trend of digital learning even before the outbreak of the pandemic. It has been in the literature since 2005 (Crompton, 2013). According to Crompton et al. (2016), research on it evolved rapidly with the advent of smart handheld devices. M-learning is a form of learning through wireless technology devices that can be pocketed or accessed anytime (El-Hussein \& Cronje, 2010). It offers new opportunities to use active learning strategies wherein students learn in their context (Cochrane,
2013) and their learning community (Quinn, 2013). M-learning also provides students better access to educational materials and services particularly to those who reside in rural and remote regions (Valk et al., 2010). Lan and Huang (2012) revealed that students expect to use mobile devices for educational purposes. With the use of technological tools like mobile phones, any individual can have access to their lessons anytime and anywhere (Hashemi et al., 2011). The use of mlearning allows learners to access, validate, and create content from their electronic devices at their convenience. It provides learning opportunities that are independent and free from any restrictions.

\section{M-Learning in the Philippine Setting}

The educational system in the Philippines is mostly based on a traditional classroom setting in which students are required to attend classes every day. Adapting modern-day pedagogies is prevalent in most of the schools in the Philippines to address the needs of today's technological society. Computers, laptops, and smartphones are the common technological resources used in the classroom that can have effects in the academic environment (Carbonilla Gorra \& Bhati, 2016). However, the advent of smartphones has modified its conventional usage due to its affordability, portability, and sustainability. Mobile phones are purchased to replace computers and notebooks in many countries such as Bangladesh, the Philippines, and Nepal (Poong et al., 2017). Smartphones have been established as an educational tool, aside from being used for communication and socialization. In the Philippines, the University of the Philippines Open University (UPOU) initiated m-learning drives in both formal and non-formal educational environments (Churchill et al., 2018). In higher education, $\mathrm{m}$ - learning plays a central role in creating modern instructional methodologies for students (Bombaes, 2018). He posited that perceived ease of usage, perceived usefulness, enjoyment, creativity, and teachers' influence are the main determinants of the student's attitude towards m-learning. He further added that most of the national university students utilize $\mathrm{m}$-technology actively. Students regarded favorable attitudes toward m-learning for its easy access, communication, collaboration, dynamic learning, and situated learning like game-based learning (Gikas \& Grant, 2013).

Nevertheless, the implementation of such educational technology in the Philippine secondary schools was not that successful because of some reasons. The research conducted by Jin and Sabio (2018) showed that most learners in chosen public high schools explored meaningful opportunities to utilize mobile devices for a range of learning tasks beyond the classroom environment. However, there are still significant digital disparities among public students, and the usage of mobile devices for learning is unequal across Manila's public schools. They further explained that certain schools do not have internet and wireless capabilities and many teachers are not equipped to incorporate handheld devices and the internet during a discussion.

\section{Psychological Impact of Technology and M-Learning}

Studies show that m-learning can have motivational benefits for students. Students using e-learning tools are more 
intrinsically motivated than those students who do not (Hartnett, 2016). Some studies revealed that m-learning has an effect on motivation, metacognition, and experienced higher psychological need satisfaction of the students (Ismail et al., 2010). Studies revealed that the Self-Determination Theory (SDT) supports m-learning. The use of mobile devices allows the volition of students, thus, promotes a perception of satisfaction, freedom, ownership, enjoyment, and accessibility (Jones \& Issroff, 2007). In addition, the study of Gilakjani et al. (2013) reveal that integrating technology in curriculum falls within the context of the constructivist framework and show that there is a correlation between constructivism and the use of technology.

M-learning is one of the most useful tools for learning nowadays. During the COVID-19 pandemic, educational institutions try to promote online student learning where learning continues to take place between teachers and students but in different areas. When educational institutions are closed due to the COVID-19 outbreak, online learning is a solution (Verawardina et al., 2020) and it can be carried out through m-learning. UNESCO (2020) said that, following the COVID-19 outbreak, students will continue to gain their rights through continuing education, even though it is done remotely. M-learning, therefore, is useful to continue the teaching and learning activities.

\section{METHODOLOGY}

This quantitative research design utilized survey questionnaires to collect the necessary information. A total of 291 students and 116 teachers from a state university in the Philippines were selected using multi-stage random sampling. An online survey was conducted in the month of September 2020. A structured questionnaire using Google form was sent to students and teachers through email, google classroom and direct message in Facebook messenger. This study utilized descriptive statistics to understand the distribution of the participants. Collected data were analyzed using the Microsoft Excel and were reported in percentage distribution using charts.

\section{RESULTS AND DISCUSSION}

With the outbreak of COVID-19, schools are temporarily closed but learning must continue. Hence, m-learning plays a crucial role in the replacement of actual face-to-face instruction. M-learning may serve as the best tool to continue learning during the crisis. This study determined the perceptions of students and teachers toward m-learning usage at present and their point of view about its adoption in the future.

It is noteworthy to describe that the 291 participating students are currently enrolled in different disciplines (e.g. Teacher Education, Engineering, Business Accountancy, and Sciences) and with varying year levels. Due to lockdowns, students went back to their respective hometowns. Some of them reside in municipalities and outside the province, while others live within the vicinity of the city. Moreover, students may have diverse cultures, socio-economic statuses, and

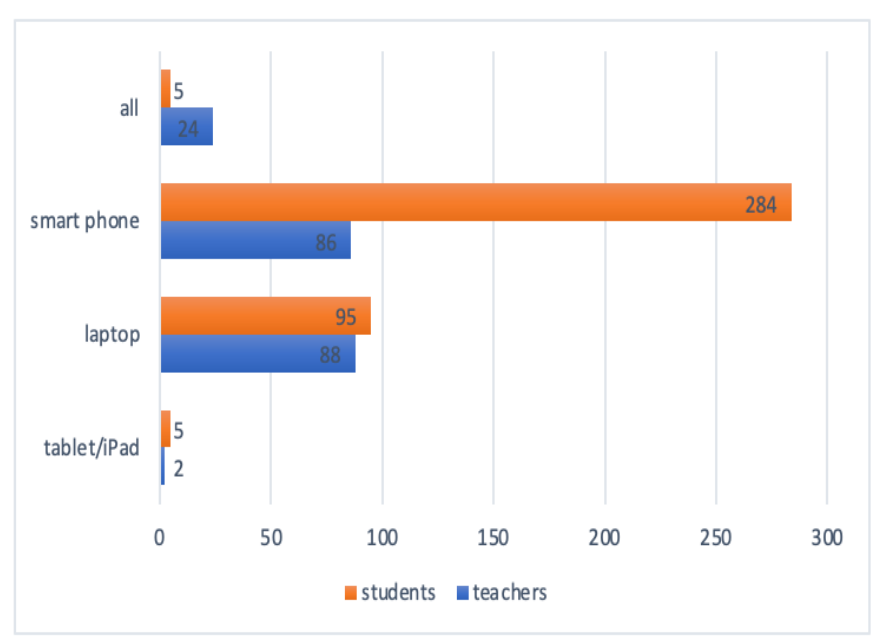

Figure 1. Students' and teachers' mobile devices

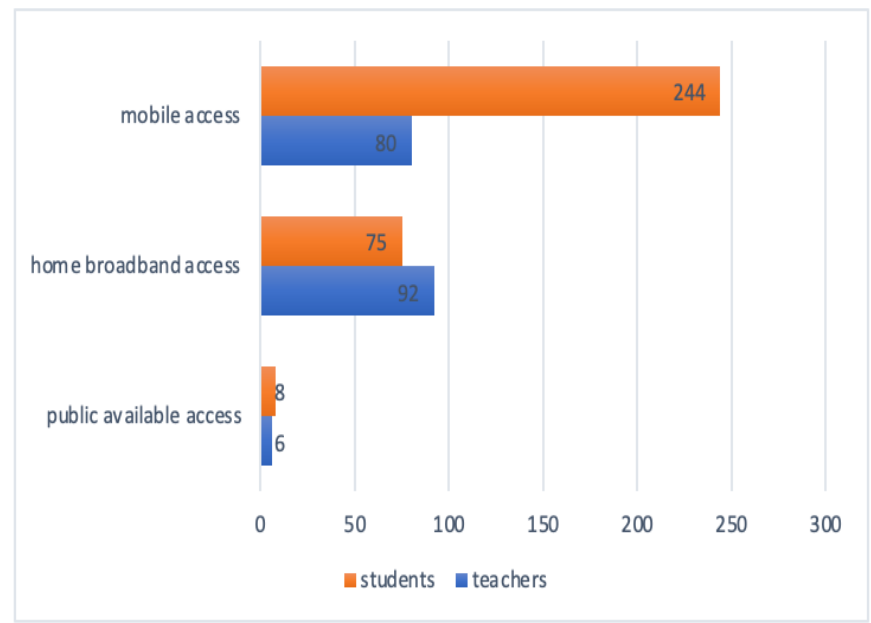

Figure 2. Students' and teachers' internet access

familiarity with technology. Such factors were not explored in this study. Only the age and gender of the participating teachers and students were determined for this particular study. Student-respondents consisted of 129 (44\%) males and 163 (56\%) females. On the other hand, teacher-respondents consisted of 42 males and 74 females with different fields of specialization. Students' age ranges from 17-27 while the teachers' age ranges from 22-62.

Figure 1 shows the different mobile devices owned by the participating students and teachers. The majority (284 or 98\%) of the students owned a smartphone while 88 (30\%) of them have laptops. Very few owned a tablet/iPad and have the three mentioned devices. When asked further, they reported that they primarily used their smartphones as a means of communication before the COVID-19 outbreak. At present, it becomes more useful as they utilized it for their online classes and learning tasks or requirements. Meanwhile, more than half of the teachers own both laptops and smartphones. It is typical for them to have such devices because of their affordability, convenience, and usage for personal or work-related activities.

Figure 2 reveals that many students ( 244 or $84 \%$ ) rely on mobile data for their internet connectivity while 75 (26\%) have their internet providers at home. In the Philippines, students usually buy prepaid cards and register to different network 


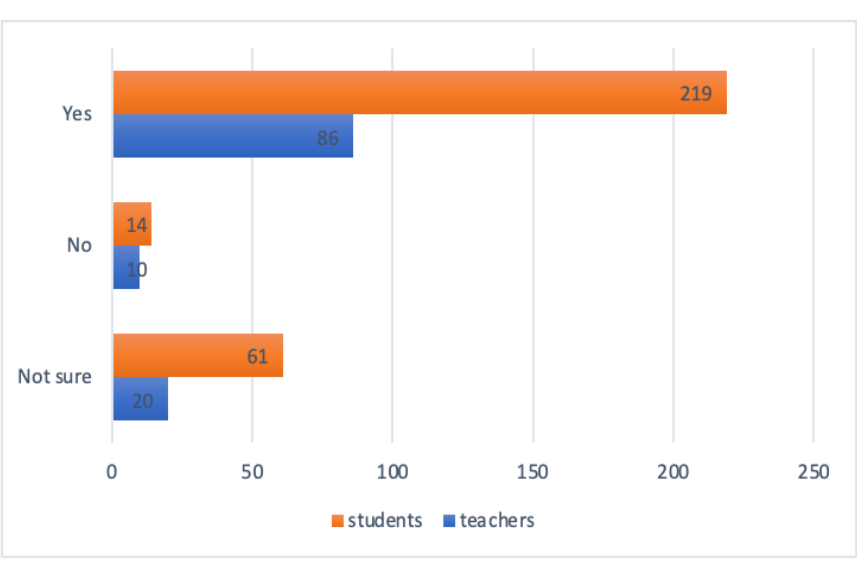

Figure 3. Students' and teachers' familiarity with the mlearning

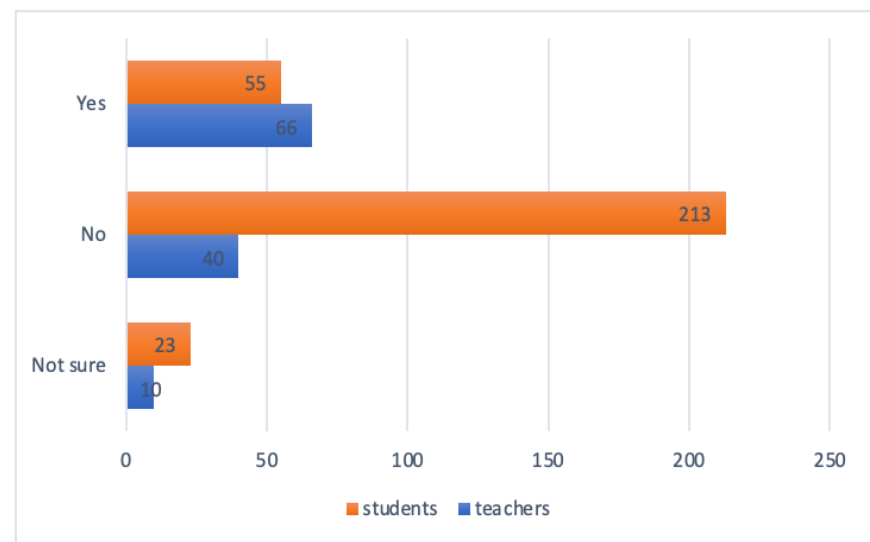

Figure 4. Students' and teachers' prior experience with mlearning

promos (e.g. Globe-GoSurf50) to avail of a bandwidth or internet data. It adds financial burden to students specifically if they have to stay online for a while to attend virtual meetings, access mobile applications, watch video tutorials, and the like. Unlike teachers, they have the means to avail either broadband or mobile data, or both. As reported, $69 \%$ of them have mobile internet access and $79 \%$ have home broadbands. In that case, designing their classes using $\mathrm{m}$ learning is not a problem for them.

Figure 3 shows that the majority of students (75\%) and teachers $(75 \%)$ reported that they are familiar with m-learning. On the other hand, a small percentage of students (5\%) and teachers (9\%) are not aware of it. Meanwhile, 31\% of the students and $17 \%$ of the teachers revealed that they are uncertain about it. It implies that students and teachers of university are cognizant of technological advances in education. Even though the university resides outside the metropolitan, its stakeholders know m-learning.

Although students reported they were familiar with $\mathrm{m}$ learning, it does not equate to their experience. Figure 4 reveals that $73 \%$ of the students were not afforded with experiences to learn using m-learning by their former teachers. It can be true because some of the students graduated from municipal high schools. It can also infer that there are public and university teachers who prefer traditional pedagogies for direct classroom instruction. As supported,

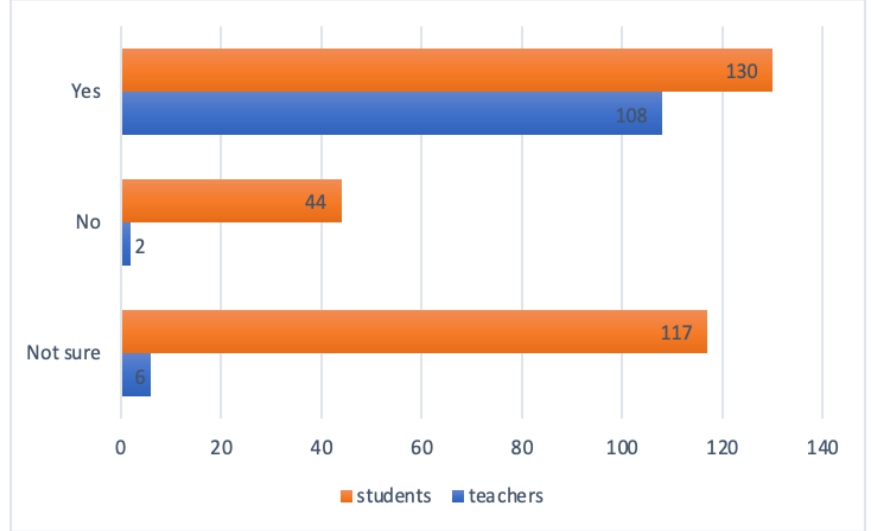

Figure 5. Students' and teachers' positive perceptions toward the m-learning usage during the pandemic

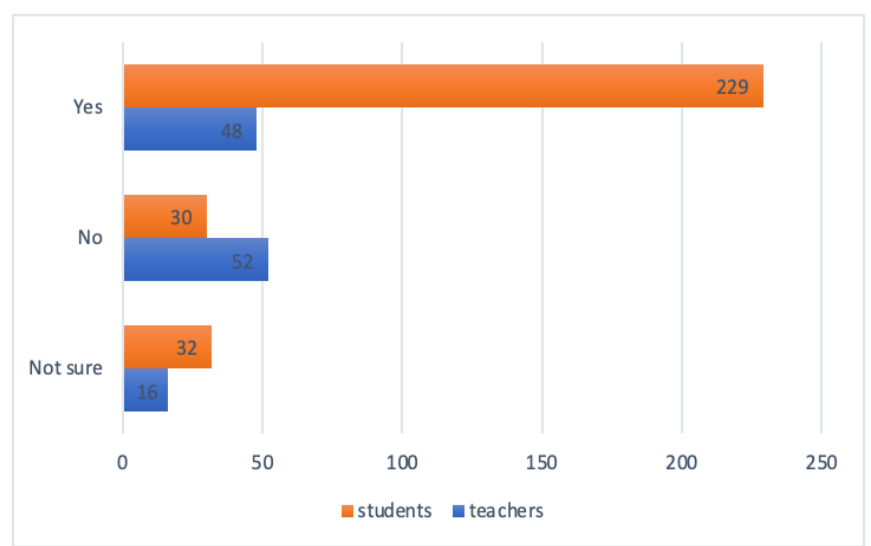

Figure 6. Perceived level of difficulty in using m-learning during the pandemic

$34 \%$ of the university's teachers said that they have no experience with m-learning before. However, there are a significant number of students (19\%) and teachers (57\%) reported that they had experience using $\mathrm{m}$-learning before the outbreak of the pandemic. It is good to know that even though classroom set-up before was traditional, some university teachers had able to integrate m-learning in their teaching.

Figure 5 tells the point of view of the respondents in terms of applicability and assistance that them-learning is offering during this time. $45 \%$ of the students and $93 \%$ of the teachers believe that $\mathrm{m}$-learning is helpful during this time of restricted learning. They primarily used their handheld devices, particularly smartphones to attend online meetings, access, and prepare their teaching and learning materials. A significant number of students (40\%) reported that they are not sure about its applicability at present. It implies that students are somewhat resistant to the change they are experiencing in the "new normal" setup and the financial cost it may incur.

In connection with the results Figure 5, Figure 6 reveals the level of difficulty of using m-learning nowadays as viewed by both teachers and students. More than half of the students (79\%) find learning difficulties using their handheld devices. This can be attributed to their previous learning set-up wherein they received direct face-to-face instruction and they were assisted by the teacher. Unlike with m-learning, self- 


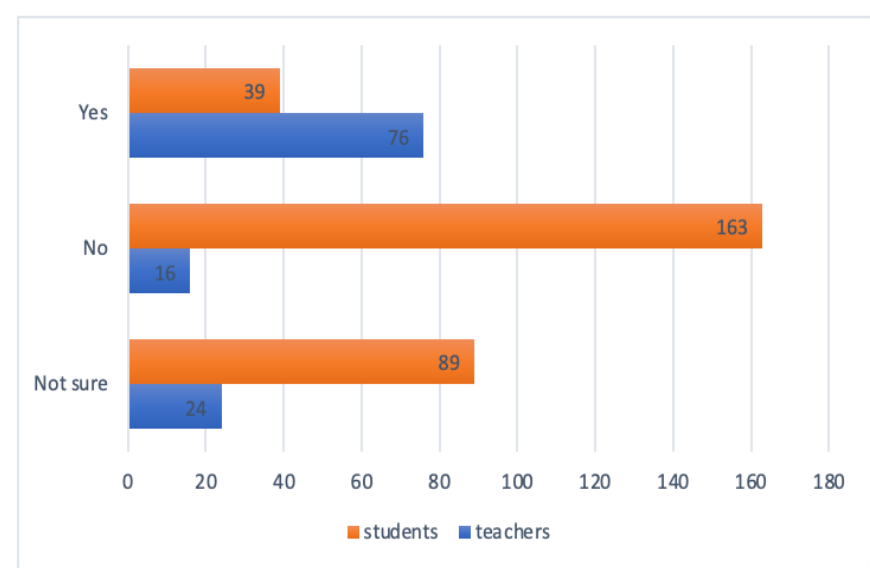

Figure 7. Students' and teachers' perceptions toward future use/adoption of the m-learning

directed learning is practiced most of the time. Again, their difficulties can also be attributed to the cost they have to spend with prepaid cards.

On the other hand, almost half of the teachers (49\%) are experiencing difficulties in the usage of $\mathrm{m}$-learning while the remaining $41 \%$ are at ease. Just like students, teachers are suffering difficulties also due to their limited exposure or usage of m-learning before. It can be inferred that the challenges they are experiencing are due to their hesitance to learn and age barriers. Some of the participants are in their 50's and 60's. Moreover, their difficulties in teaching material preparations can be another contributory factor since they have to make new materials suited for m-learning.

Figure 7 shows the perceptions of the respondents toward the adoption of m-learning after the pandemic. $56 \%$ of the students disagreed with it, while $13 \%$ showed a favorable attitude. Although m-learning has been useful nowadays, a financial factor may have caused their disagreement. The expenses they acquire every time they have to buy mobile data become their additional burden. Furthermore, their current difficulties may add to their demotivating factor to adopt it in the future. Nevertheless, $66 \%$ of teachers are in favor of adopting the use of m-learning after the pandemic. Even though the country belongs to a world country and the university lies in a sub-urban province, teachers are open to innovations if it is for the betterment of education.

M-learning offers a positive contribution to learning continuity during this crisis. A mobile phone-facilitated learning is capable of providing better access to educational materials and services to students who reside in rural and remote regions. Also, the use of technology promotes adaptive learning (Goh \& Sandars, 2020) and flexibility (Tømte et al., 2013). It has motivational benefits to students like freedom, ownership, communication, enjoyment, and accessibility (Jones \& Issroff, 2007). However, there are also barriers to the use of mobile phones. In the study of Stockwell (2010), he mentioned the technological, pedagogical, psychological, or even environmental barriers often prevent learners from selecting mobile devices like smartphones for learning activities, even though they have a positive view of $\mathrm{m}$ learning. Since they are not accustomed to this kind of approach, the use of m-learning cannot be maximized. Meanwhile, according to Stockwell (2007), some teachers resist change in teaching and learning with new technology because they do not think of themselves as part of a new learning culture. Lack of time to learn new software and technology, lack of support, lack of technology infrastructure, and lack of specific technologies that could address specific needs of students and resistance to changing their traditional approaches were enumerated by Vrasida and Glass (2005) as factors why teachers do not want to use new technology.

\section{CONCLUSIONS}

The COVID-19 pandemic poses a unique challenge to all educational settings across the globe. The teaching and learning environment has increasingly shifted due to the constraints making m-learning an indispensable means for educators and students at the university being studied. It serves as the backbone of support in the academic environment because of its enabling capability to connect teachers to their clientele and carry out different teaching and learning tasks during this time of restricted learning. Smartphones serve as the primary tool in education at the university. Despite the usefulness of m-learning during the pandemic, students are unlikely to adopt it in the future compared to teachers who reported favorable responses. This can be attributed to some demotivating factors in the side of students. Among the many services provided by the university, it should give support such as infrastructures and internet connectivity on the campus. Common to many state universities in the Philippines is the lack of technological infrastructures and internet access before and during the pandemic. It is noteworthy to address that both teachers and students are familiar with m-learning. Nevertheless, they reported a lack of prior exposure. The institutional support through constant technological and pedagogical training for teachers and technology infrastructure for students will be helpful to ease their difficulties and transitions in times of emergencies like now. Filipino teachers and students are adaptive and open to changes, but they need support from the institution. This present crisis may pave the way for the university's policymakers, and educators to realize that learning should be continually improved and put into a modern context. They have to work hand in hand to deliver instructions effectively.

Some limitations need to consider for future research. I, the researcher, primarily relied on the honesty of the respondents to come up with reliable results. Yet, the reasons behind their answers were not explored thoroughly. To shed light on the quantitative results, open-ended questions will be helpful. Since the survey was carried out through google forms, the respondents of this study were those who have online access. The results cannot represent those who have no internet access. Also, students and teachers outside the university's main campus were not surveyed. There are community colleges in different municipalities of the province that must include. Such limitations present an opportunity to increase the sample size and change the design into mixedmethod research.

Funding: No external funding is received for this article.

Ethics approval and consent to participate: Not applicable. 
Availability of data and materials: All data generated or analyzed during this study are available for sharing when appropriate request is directed to corresponding author.

\section{REFERENCES}

Bombaes, A. (2018). Student's intentions to use m-learning: An empirical perspective from the Philippines. Business and Economic Research, 8(1), 68-83. https://doi.org/10. 5296/ber.v8i1.12305

Carbonilla Gorra, V., \& Bhati, S. S. (2016). Students' perception on the use of technology in the classroom at higher education institutions in the Philippines. Asian Journal of Education and e-Learning, 4(3), 92-103.

Churchill, D., Pegrum, M., Churchill, N. (2018). The implementation of mobile learning in Asia: Key trends in practices and research. In J. Voogt, G. Knezek, R. Christensen, \& K.W. Lai (Eds.), Second handbook of information technology in primary and secondary education (pp. 1-41). Springer. https://doi.org/10.1007/978-3-31953803-7_54-1

Cochrane, T. (2013). M-learning as a catalyst for pedagogical change. In Z. L. Berge, \& L. Muilenburg (Eds.), Handbook of mobile learning. Routledge.

Crompton, H. (2013). The benefits and challenges of mobile learning. Learning and Leading with Technology, 41, 38-39.

Crompton, H., Burke, D., Gregory, K. H., \& Gräbe, C. (2016). The use of mobile learning in science: A systematic review. Journal of Science Education and Technology, 25(2), 149-160. https://doi.org/10.1007/s10956-015-9597-x

Dong, C., Goh, P. S. (2015). Twelve tips for the effective use of videos in medical education. Medical Teacher, 37(2), 140145. https://doi.org/10.3109/0142159X.2014.943709

El-Hussein, M. O. M., \& Cronje, J. C. (2010). Defining mobile learning in the higher education landscape. Journal of Educational Technology \& Society, 13(3), 12-21.

Gikas, J., \& Grant, M. M. (2013). Mobile computing devices in higher education: Student perspectives on learning with cellphones, smartphones \& social media. The Internet and Higher Education, 19, 18-26. https://doi.org/10.1016/ j.iheduc.2013.06.002

Gilakjani, A. P., Lai, L., \& Ismail, H. N. (2013). Teachers' use of technology and constructivism. International Journal of Modern Education and Computer Science, 5(4), 49-63. https://doi.org/10.5815/ijmecs.2013.04.07

Goh, P.-S., \& Sandars, J. E. (2020). A vision of the use of technology in medical education after the COVID-19 pandemic. MedEdPublish, 9(1). https://doi.org/10.15694/ mep.2020.000049.1

Hartnett, M. (2016). The importance of motivation in online learning. In M. Harnett (Ed.), Motivation in online education (pp. 5-32). Springer. https://doi.org/10.1007/978-981-100700-2_2

Hashemi, M., Azizinezhad, M., Najafi, V., \& Nesari, A. J. (2011). What is mobile learning? Challenges and capabilities. Procedia-Social and Behavioral Sciences, 30, 2477-2481. https://doi.org/10.1016/j.sbspro.2011.10.483
Ismail, I., Gunasegaran, T., Koh, P. P., \& Idrus, R. M. (2010). Satisfaction of distance learners towards mobile learning in the Universiti Sains Malaysia. Malaysian Journal of Educational Technology, 10(2), 47-54.

Jin, W., \& Sabio, C. J. (2018). Potential use of mobile devices in selected public senior high schools in the city of Manila Philippines. International Journal of Learning, Teaching and Educational Research, 17(4), 102-114. https://doi.org/ 10.26803/ijlter.17.4.7

Jones, A., \& Issroff, K. (2007). Motivation and mobile devices: Exploring the role of appropriation and coping strategies. Research in Learning Technology, 15(3), 247-258. https://doi.org/10.3402/rlt.v15i3.10934

Lakhal, S., Bateman, D., \& Bédard, J. (2017). Blended synchronous delivery mode in graduate programs: A literature review and its implementation in the master teacher program. Collected Essays on Learning and Teaching, 10, 47-60. https://doi.org/10.22329/celt.v10i0. 4747

Lan, Y.-F., \& Huang, S.-M. (2012). Using mobile learning to improve the reflection: A case study of traffic violation. Educational Technology \& Society, 15(2), 179-193.

Poong, Y. S., Yamaguchi, S., \& Takada, J. I. (2017). Investigating the drivers of mobile learning acceptance among young adults in the World Heritage town of Luang Prabang, Laos. Information Development, 33(1), 57-71. https://doi.org/10.1177/0266666916638136

Quinn, C. (2013). A future for m-learning. In Z. L. Berge, \& L. Y. Muilenburg (Eds.), Handbook of mobile learning. Routledge.

Stockwell, G. (2007). Vocabulary on the move: Investigating an intelligent mobile phone-based vocabulary tutor. Computer Assisted Language Learning, 20(4), 365-383. https://doi.org/10.1080/09588220701745817

Stockwell, G. (2010). Using mobile phones for vocabulary activities: Examining the effect of platform. Language Learning \& Technology, 14(2), 95-110.

Tømte, C., Kårstein, A., \& Olsen, D. S. (2013). IKT i lærerutdanningen: På vei mot profesjonsfaglig digital kompetanse? [ICT in teacher education: Towards professional digital competence?]. NIFU Report. https://www.nifu.no/publications/1027114/

UNESCO. (2020). Distance learning solutions. UNESCO. https://en.unesco.org/covid19/educationresponse/solutio ns

Valk, J. H., Rashid, A. T., \& Elder, L. (2010). Using mobile phones to improve educational outcomes: An analysis of evidence from Asia. The International Review of Research in Open and Distributed Learning, 11(1), 117-140. https://doi.org/10.19173/irrodl.v11i1.794

Verawardina, U., Asnur, L., Lubis, A. L., Hendriyani, Y., Ramadhani, D., Dewi, I. P., Darni, R., Betri, T. J., Susanti, W., \& Sriwahyuni, T. (2020). Reviewing online learning facing the COVID-19 outbreak. Journal of Talent Development and Excellence, 12(3s), 385-392. 
Vrasida, C., \& Glass, N. V. (2005). ICT-related teacher professional development: Models and strategies. Yearbook of the National Society for the Study of Education, 106(2), 87-102. https://doi.org/10.1111/j.17447984.2007.00116.x 